\title{
APPLICATION OF A MEASURING ARM WITH AN INTEGRATED LASER SCANNER IN THE ANALYSIS OF THE SHAPE CHANGES OF FORGING INSTRUMENTATION DURING PRODUCTION
}

\section{ZASTOSOWANIE RAMIENIA POMIAROWEGO ZE ZINTEGROWANYM SKANEREM LASEROWYM DO ANALIZY ZMIAN KSZTAŁTU OPRZYRZĄDOWANIA KUŹNICZEGO W TRAKCIE PRODUKCJI*}

\begin{abstract}
In the article, the authors present an innovative approach consisting in an analysis of the wear (shape changes) of one of the forging tools directly during production, with the use of a laser scanner, without the necessity of their disassembly from the forging unit. The tests consisted in direct measurements of the shape changes of cyclically sampled forgings during the forging process (every 1000 item), and next, based on the proceeding wear, an indirect analysis was performed of the shape change of the impression of the selected tool, i.e. a filler. At the time of the short technological intervals in the process, direct measurements were performed of the tool itself, with the purpose of verifying the results of the forgings' measurement in relation to the actual changes in the tool. The performed analyses showed a good agreement of the geometrical properties of the surfaces (of the selected forgings representing the proceeding wear of the tool) and the geometrical defect of the working impression of the tool, based on the direct measurements during the production process. The obtained results allow for a fast analysis of the forging tool life with respect to the quality and the quantity (of material defect), which, in consequence, leads to significant economical savings. The proposed method makes it possible to make decisions on the time period of the tool operation based on the tools' actual wear, instead of-as has been the case in forging plants up till now - after the given maximal number of forgings has been made or a premature tool damage has been observed.
\end{abstract}

Keywords: scanning of forging tools, tool life, failure mechanisms.

\begin{abstract}
W artykule autorzy przedstawili innowacyjne podejście polegające na analizie zużywania się (zmian ksztattu) jednego z narzędzi kuźniczych bezpośrednio w trakcie produkcji przy wykorzystaniu skanera laserowego, bez konieczności ich demontażu z agregatu kuźniczego. Badania polegały na bezpośrednich pomiarach zmian kształtu cyklicznie pobieranych odkuwek podczas procesu kucia (co 1000szt), a następnie na podstawie postępującego zużywania dokonywana była w sposób pośrednia analiza zmian ksztattu wykroju wybranego narzędzia - wypetniacza. Natomiast w momencie krótkich przerw technologicznych w procesie przeprowadzano bezpośrednie pomiary samego (analizowanego) narzędzia w celu weryfikacji wyników pomiaru odkuwek w stosunku do rzeczywistych zmian narzędzia. Przeprowadzone analizy wykazaty duża zgodność cech geometrycznych powierzchni (wybieranych odkuwek odzwierciedlajacych zużywanie się narzędzia), a ubytkiem geometrycznym wykroju roboczego narzędzia na podstawie bezpośrednich pomiarów podczas produkcji. Uzyskane rezultaty pozwolity na dokonanie szybkiej analizy trwatości narzędzia kuźniczego pod względem jakościowym i ilościowym (ubytku materiatu), co w konsekwencji prowadzi do znacznych oszczędności. Zaproponowana przez autorów metoda pozwala na podejmowanie decyzji o czasie eksploatowania narzędzi na podstawie ich rzeczywistego zużycia, a nie, jak to ma miejsce obecnie w kuźniach, po określonej maksymalnej ilości wykonanych odkuwek lub zaobserwowanego w tym okresie przedwczesnego uszkodzenia narzędzia.
\end{abstract}

Stowa kluczowe: skanowanie narzędzi kuźniczych, trwałość, mechanizmy niszczace.

\section{Introduction}

The high competition on the forged product supply market more and more often makes the quality of the offered forgings, beside the price of the product, the decisive parameter in the selection of the supplier. This is especially important when the recipient of the product is the automotive or aviation industry, where these requirements are at the highest level. The process of die forging is one of the most difficult production processes with respect to implementation. Despite the fact that this technology is relatively well-known, the proper production, especially of forgings of a complicated shape, which will meet the requirements regarding the precision and quantity made by the recipients, requires high experience from the technologists and operators. At each stage of the forging process, there is a potential risk of error, which lowers the quality of the produced forgings. One of the basic factors affecting the forging quality is the life of the ap-

(*) Tekst artykułu w polskiej wersji językowej dostępny w elektronicznym wydaniu kwartalnika na stronie www.ein.org.pl 
plied tools, as their wear causes a change in the shape of the product, and any surface flaws of the tools (cracks, defects) are represented on the forged product. That is why a detailed quality control is so important during production. At present, such check-ups consist in a visual assessment of the quality of the produced element as well as a measurement of selected control points with the use of traditional measuring devices or simple curve gauges. These methods do not, however, provide the possibility to assess the quality and shape of the whole element and so, more and more often, other measuring methods are applied, such as the ones which use the coordinate measuring technique $[3,7,9,10]$.

The coordinate measuring technique provides a lot of possibilities for the development of modern metrological thought $[12,16,27]$. In the industrial coordinate technology, one can observe new trends. The most conspicuous change is the necessity of using 3D models during measurements which are in accordance with the standards of the GPS measurement chain (Geometrical Product Specifications) [10, $11,21,26]$. Another important trend is increasing the number of measurement points necessary for determining the analyzed geometrical properties. One of those properties is the volumetric wear parameter, which can also be used in the analysis of the shape changes of forging tools, with the purpose to prognosticate their wear process. Among others, this parameter is used in medicine. For example, in works [1, $17,18]$, the authors present the use of a coordinate measuring machine equipped with a contact measuring head for analyzing the volumetric wear parameters of the spherical surfaces of joint prostheses. In work [15], the authors expand the research concerning the analysis of the effect of the change of numerous scanning parameters, with the use of the contact scanning measuring head, whereas the authors of works $[2,18,25]$ analyze the 'beneficial' effect of increasing the number of measurement points on the accuracy of the determined volumetric parameters.

At present, the industry is increasingly interested in mobile measuring devices. These undoubtedly include measuring arms equipped with linear laser scanners with dedicated specialized software. Measuring arms, through their mobility and universality, are an alternative for the coordinate measuring machines in applications which allow for a lower measuring accuracy [14, 20]. For example, the accuracy of a mobile measuring arm was discussed in work [4], whose authors performed tests consisting in an evaluation of the representation of the nominal shape with the use of the arm as well as the coordinate machine. The 3D scanning technique, also with the use of measuring arms, is mainly applied for the product end quality control [14, 22, 28]. These measurements are the most often based on the assessment of the shape errors of the determined contour and surface $[5,14]$. The available literature more and more frequently discusses applications of this kind of methods for the measurement, control and evaluation of the state of swaging tools. An example of such application of the $3 \mathrm{D}$ scanning method $[13,23]$ is the use of an optical scanner for the determination of the shape errors of the given surface and next, on the basis of the obtained data, providing the geometrical specification for the process of rebuilding. Another application of the 3D scanning method with the use of scanners $[5,6,8,19,24]$ is the use of the analysis of the shape errors of the given surface for the evaluation of the wear of the forging tools - nitrided or coated with hybrid layers. These analyses consist in a comparison of the images obtained from the scanning of the new forging tool before its operation or a reference CAD model and next of the same tool after the forging process, by way of determining the shape errors of the analyzed surface.

The aim of the work is to prove the possibilities of applying a measuring arm with an integrated laser scanner in the control and analysis of the wear process of the selected forging tool, i.e. an upper filler (used in the second operation of die forging), on the basis of the measurement of the shape changes of cyclically sampled forgings, directly during the production process.

\section{Test subject}

In the industrial production process, controlling the quality and state of the applied tools is quite difficult and troublesome, as it is often connected with the necessity of the tools' disassembly, which causes long production intervals. A continuous analysis of the quality and life of the tools directly on the production line is important due to the fact that the flaws occurring on the tool are 'automatically' transferred to the forging. Often, even a minor defect or wear of the tool in the first operation (preliminary forging) of the multi-operational forging process makes obtaining a forging which meets all of the requirements difficult in the last operation, i.e. the finishing (calibrating) forging [7]. That is why a useful solution can be the possibility to evaluate the shape changes of the tool impressions in the particular operations, performed based on a cyclic control of the tools (measurement through scanning), without the necessity of their disassembly from the forging press (Fig. 1).

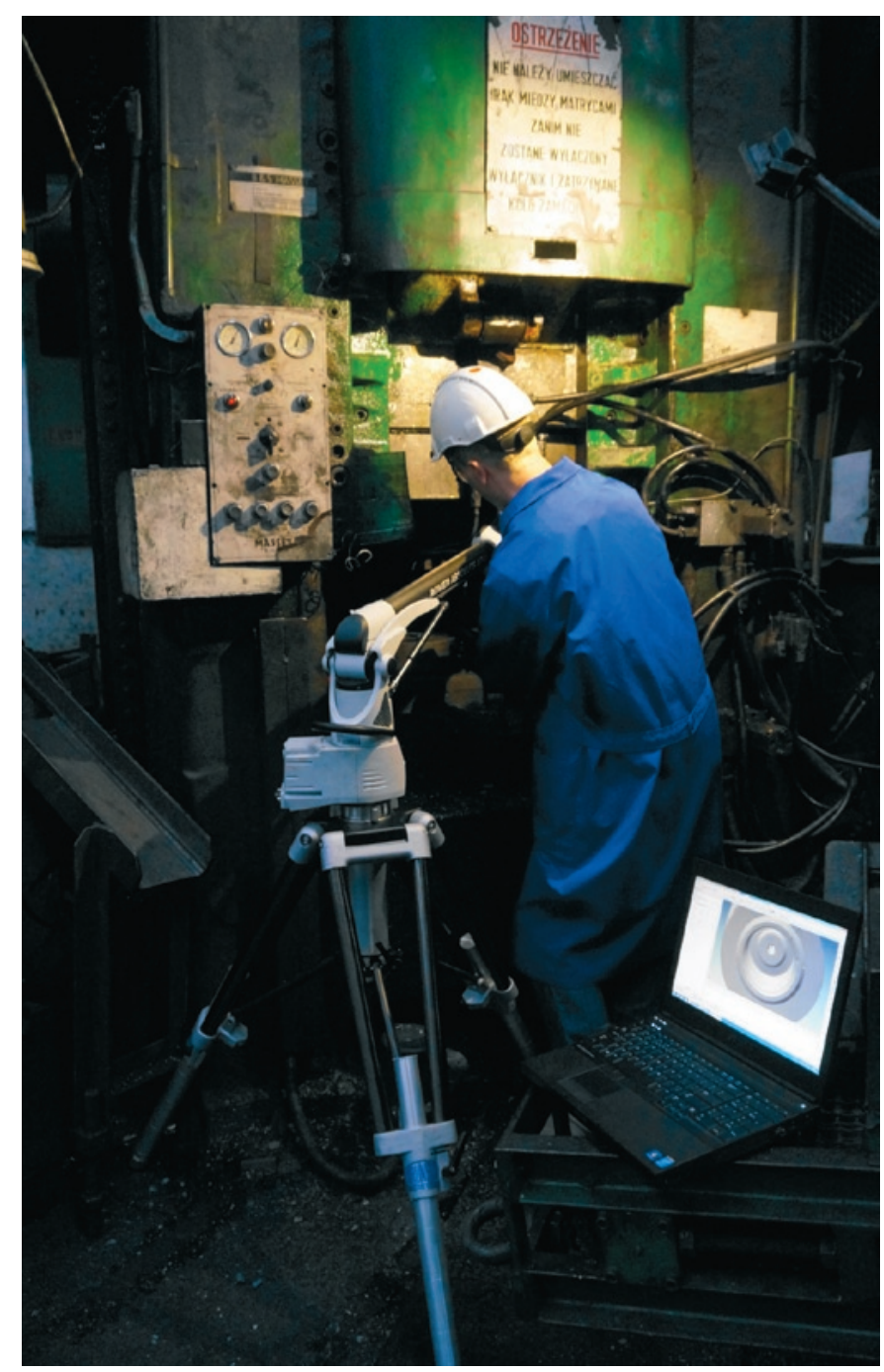

Fig. 1. View of the press together with assembled forging tools for gearbox lid forging and the measurement by way of filler scanning with the use of the measuring arm, performed directly on the production line

The industrial process of hot die forging of a gearbox lid forging (Fig. 2), used in one of motor-car brands was chosen for the analysis. This element is assembled at the output of the transmission drive shaft. The process is realized in three operations on the P-1800T press. The consecutive operations are: upsetting, blocking and final forging. The forged material is $\mathrm{C} 45$ steel with the billet dimensions: diameter $55 \mathrm{~cm}$, length $95 \mathrm{~mm}$, weight $1,77 \mathrm{~kg}$. The initial temperature 
a)

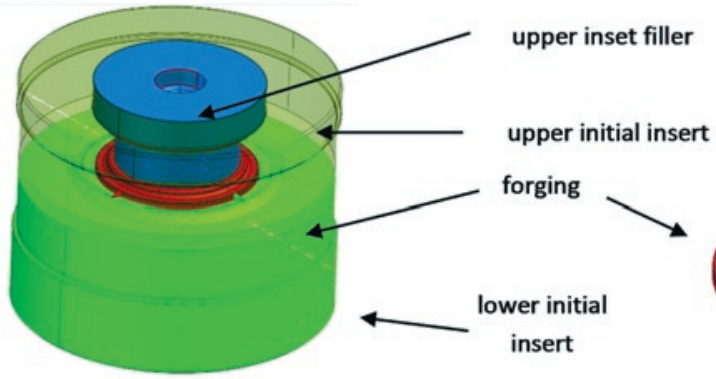

b)

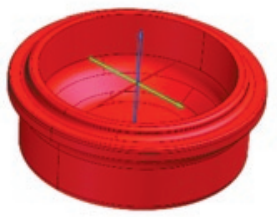

Fig. 2. Schematics of blocking for the produced element: a) tool set, b) forging

\section{Tool and measuring method descrip- tion}

In the measurements of the shape changes of the forgings and the filler, the measuring arm ROMER Absolute ARM 7520si was used (Fig. 4) together with the Polyworks 2014 software and the Real Time Quality Meshing technology. The measuring arm is equipped with seven rotation axes. Each axis includes an absolute encoder which measures the rotation angle of the kinematic pair, which does not require initialization or heating. The arm enables contact

of the billet is $1150{ }^{\circ} \mathrm{C}$. The forging tools were made of tool steel for hot operations - WCL (1.2343). After the thermal treatment, the tools assigned for the second and third operation additionally undergo thermo-chemical treatment (nitriding), with the purpose to increase their abrasive wear resistance. During their operation, these tools undergo very high cyclic thermal (from 80 to $600^{\circ} \mathrm{C}$ ) and mechanical (0-800 MPa) loads. As a result of such extreme working conditions, their wear rate is high.

A detailed analysis was performed of one of the tools used in the second forging operation - the upper insert filler (Fig. 2a). The tools used in the second operation (blocking) undergo the highest loads, due to the fact that in this operation, the forging is formed to the highest extent. For the selected filler, tests were conducted in order to determine its tool life directly on the production line (without its disassembly from the forging press), on the basis of the measurements of the forgings' shape changes during the forging process (Fig. 2b) by way of scanning. At the time of the short technological intervals in the process, direct measurements were performed of the (analyzed) tool itself, with the purpose to verify the results of the forging measurement in relation to the actual changes in the tool (Fig. 3).

The average tool life is relatively low and equals about 6700 forgings, which is connected with the occurrence of many destructive mechanisms simultaneously. The average tool life for the remaining tools in this process equals about 9000 items.

The most frequent defects of this tool include: plastic deformations, mechanical microcracks, thermal microcracks, wear through abrasion, fracture and chipping off of tool parts. At the time of the whole production process, the shape changes proceed with varying intensity at the particular stages of operation, which additionally complicates the analysis of the tool life as well as the actions connected with this measurement [9].

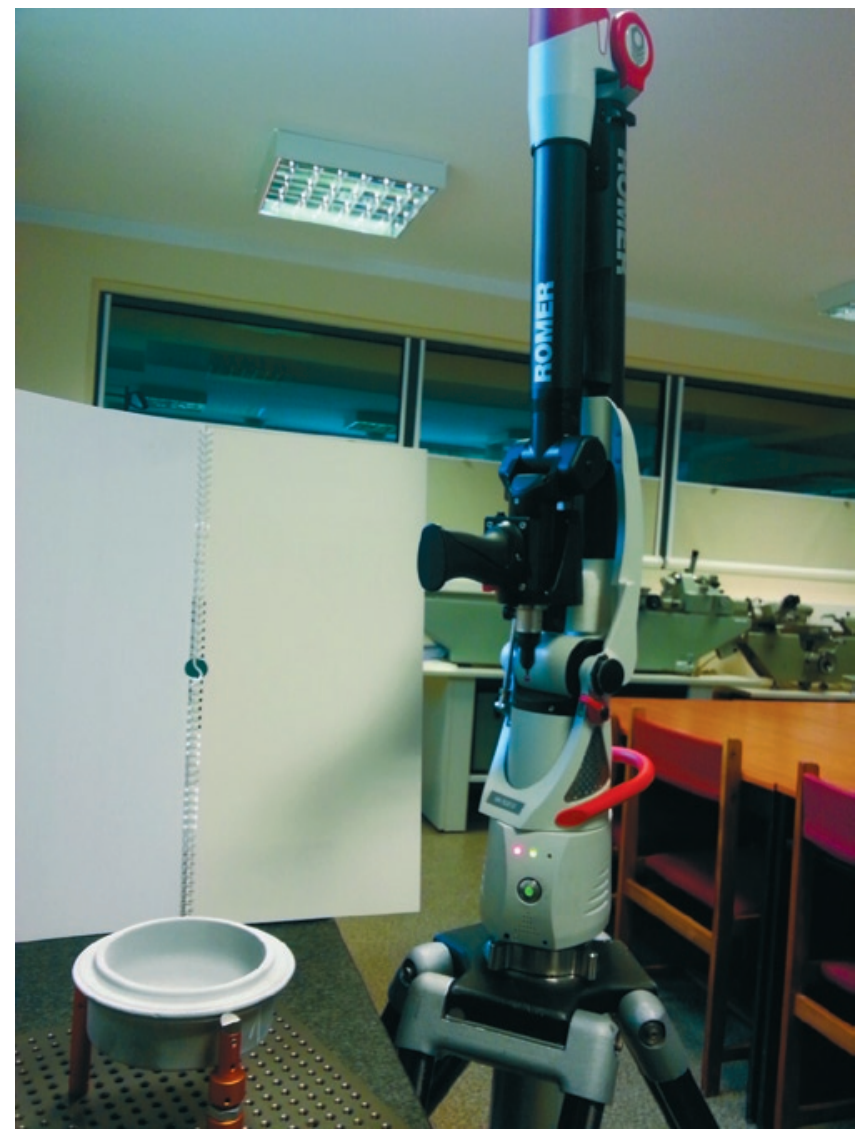

Fig. 4. Measuring station for laboratory tests of forgings with the ROMER Absolute ARM 7520si measuring arm equipped with an integrated laser scanner

a)

b)

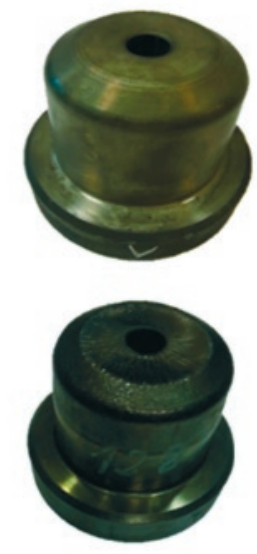

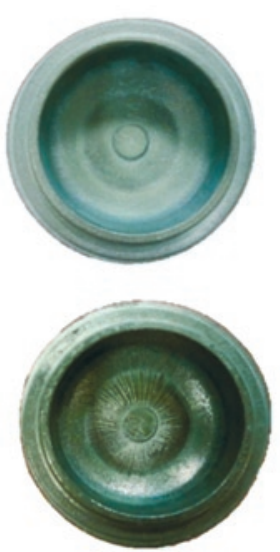

Fig. 3. Analyzed upper insert filler: a) new - before operation, with the forging from the beginning of operation, b) worn - after 12500 forgings, with the forging from the end of tool exploitation measurements as well as optical ones. For the tests, the non-contact measuring method was chosen with the use of the laser scanning system RS2 integrated with the arm. The integrated RS2 scanner characterizes in the possibility to collect up to 50000 points/s for 1000 points on the line at the linear frequency of $50 \mathrm{~Hz}$.

In order to determine the possibility of applying 3D scanning in the tests of tool shape changes in the analyzed process, it was necessary to determine the optimal surface parameters for the comparison of the measuring data obtained from scanning the filler before and after operation. The selection of the optimal surface fragments aimed at the possibility to obtain the proper data comparison method and thus to assure the most accurate measuring results for the desired shape change. 


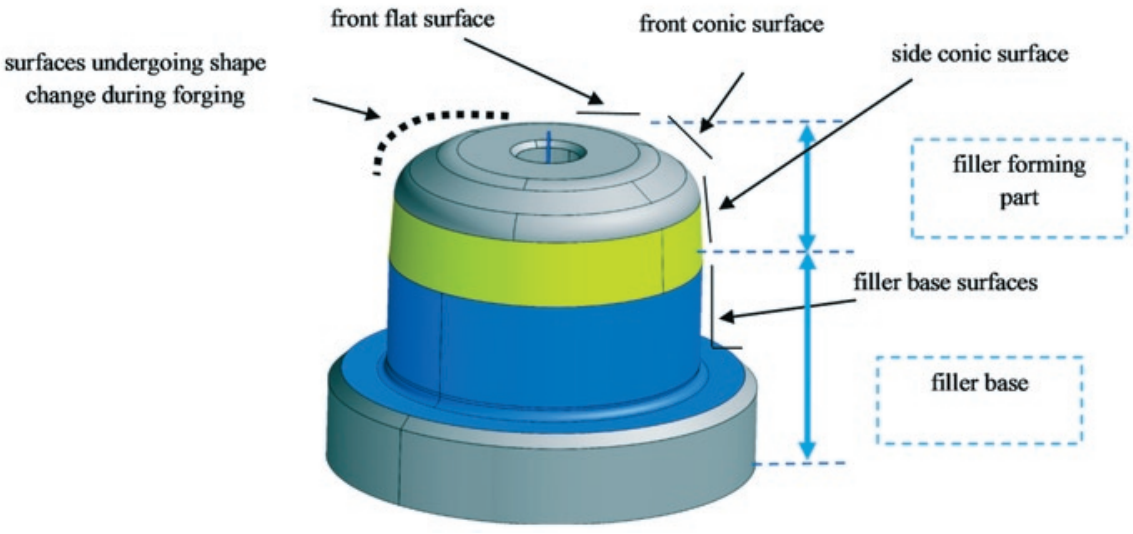

Fig. 5. Functional division of the filler surface with marked surfaces which change their shape during forging

In the data approximation process, the best-fit method is used which applies the Gauss approximation algorithm consisting in calculating the mean element. The calculations involve the use of the principle of the least squares of the deviations of the nominal points from the calculated ones. Such a method can cause the results to be encumbered with a large error, when an inappropriate surface for approximation is selected, especially in the case of significant shape errors. The authors also analyzed the effect of the selected reference surface during scanning on the obtaining of results which most correspond to the actual wear value. To that end, verification of the measurement results was performed by means of the laser scanner (in selected points) by way of validation (measurement) on a coordinate machine. The performed verification confirmed the possibility to obtain the declared accuracy of the RS2 linear scanner at the level below 0.058 [mm].

The analyzed filler can be divided into the forming part and the base (Fig. 5). The filler base is responsible for the proper basing of the surfaces forming the forging in relation to the remaining parts of the built-up forging tool.

The surfaces forming the forging belonging to the forming part of the filler (front flat, front conic, side conic), which are responsible for fulfilling the geometrical properties of the end forging product in the second operation, as a result of wear, change their shape together with the number of the produced forgings.

\section{Verification of proposed method of filler wear analysis}

First, scanning with the use of the Real Time Quality Meshing technology was performed. The result of the particular measurements by means of the $3 \mathrm{D}$ scanning technology is a cloud of points. Next, based on the obtained cloud of points, the program opened a polygonal surface consisting of elementary triangles, representing the shape of the measured object.

Fig. 6 shows a comparison of the shape changes in the forgings after a given number of cycles and after the filler's wear, for which, in order to verify the proposed method, measurements with the use of the measuring arm together with the scanner were performed during the short technological intervals in the forging process. The presented comparison of the forging scans and the corresponding tools (Fig. 6) b)
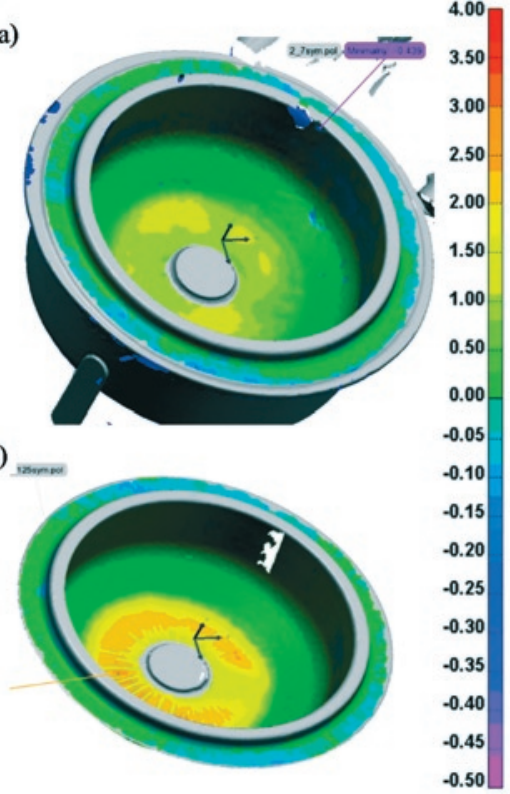
item

\section{Test results} placed by the operator. is made in the middle and towards the end of the forging process (filler operation), in order to exhibit the increasing areas of wear.

In the analysis of the growth of the volume in the case of the forgings as well as its loss, one can assume that they are both at a similar level. For the forging-filler set of 6000 items, the maximal material growth in the normal direction for the forging equals about $+1,5 \mathrm{~mm}$, whereas for the tool, the loss is at the level of about $1,4 \mathrm{~mm}$. For the set of 12500 items, in turn, the maximal differences in the normal direction equal: $+2,3 \mathrm{~mm}$ for the forging and $2,4 \mathrm{~mm}$ for the filler. Certain differences in the obtained results can be caused by the particular measuring accuracy of the scanner as well as the temperature conditions of the scanned elements (filler temperature: about $120-150^{\circ} \mathrm{C}$, forging temperature: ambient).
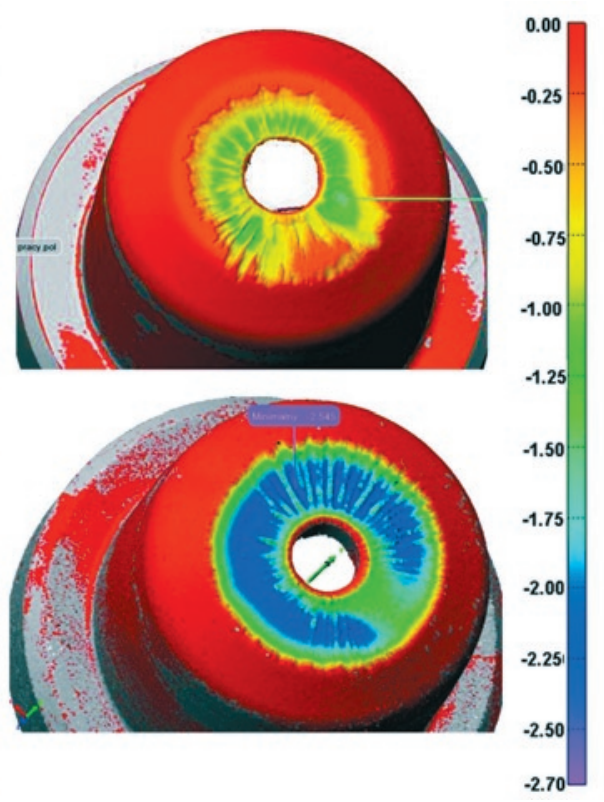

Fig. 6. Comparison of scans of the inner part of the forgings and the corresponding tools, in the form of quantitative shape changes in relation to the CAD models of the nominal forging and the tool, every: a) 6000, b) 12500

With the purpose of a more thorough analysis of the filler's wear, on the basis of the measurements of the shape changes of the forgings, scanning was performed for a forging series (every 1000 items), produced by the analyzed filler in the total amount of over 12500 items. Due to the fact that the forging's temperature, after the forging operation, is about $1000^{\circ} \mathrm{C}$, which makes it impossible to tag the forgings with the purpose of further identification, a specially prepared container with partitions was used (Fig. 7), in which the forgings were

Fig. 8 presets a comparison of selected scans of the inner part of the forgings, in the form of quantitative shape changes in relation to the CAD model of the nominal forging.

As it was to be expected, the images with the scans for the increasing number of forgings point to a proceeding wear of the tool, i.e. the filler. The wear (on the basis of the volume change) is localized in the central part, in the vicinity of the knock-out opening (grey circle) and it is irregular. This probably results from the manner of providing the 


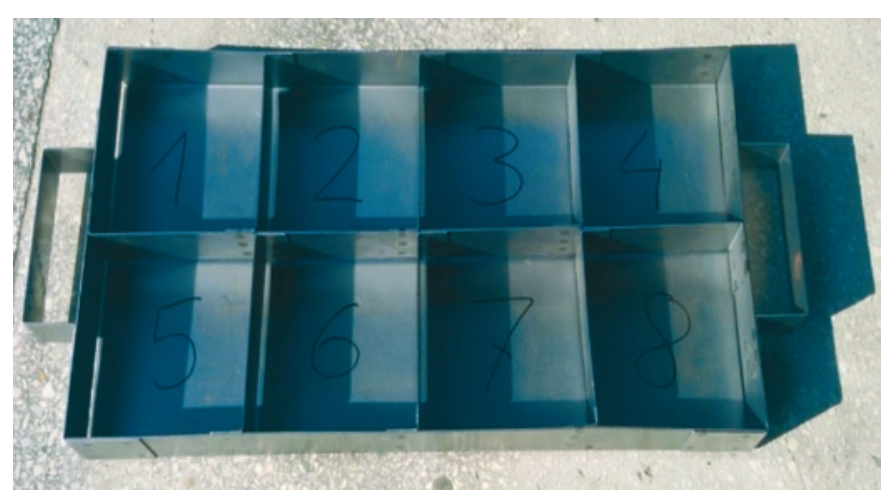

Fig. 7. Box for placing the forgings

a)

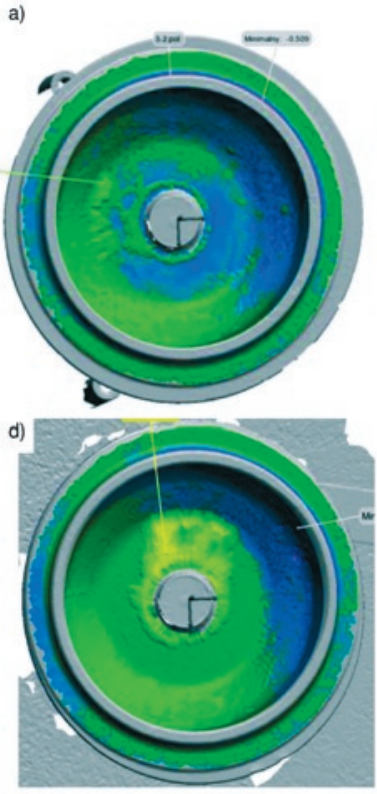

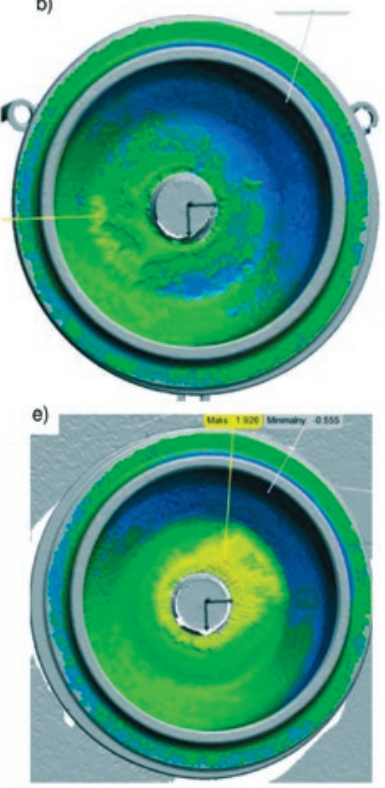

c)

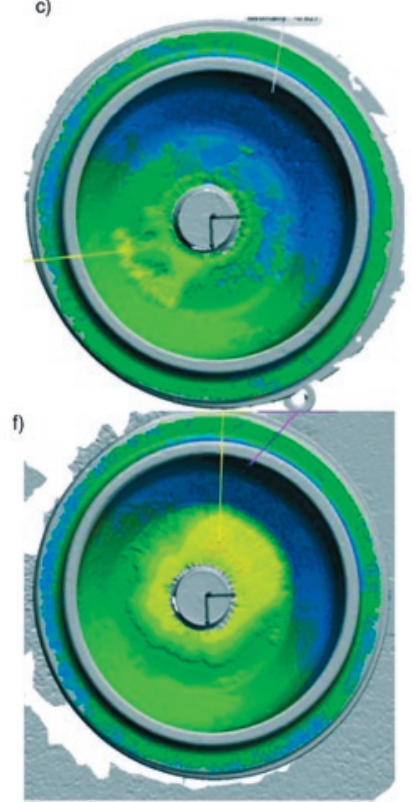

cooling and lubricating agent (inappropriate position of the lubricating nozzles). And so, the proposed method would allow for an early detection of this kind of disadvantageous changes in the lubricating process and the appropriate correction of the position of the lubricating nozzles, which would surely prolong the life of the tools.

Fig. 9. Shows a diagram with a comparison of the material loss (volume changes) of the filler on the basis of the volume changes (adequate growth) for the consecutive forgings from a given series.

On the basis of the presented diagram (Fig. 9) resembling the classic wear curve (Lorenz curve), we can observe interesting relations and distinguish a few ranges (periods) of wear. And so, the wear of the analyzed filler based on the forging scan analysis increases very rapidly at the beginning of the forging process up to about 1000 items (period I). This is connected with the approximation of the whole system, in which we observe a transformation of the initial state of the outside lay-

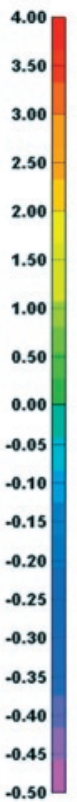
ers of the elements of the filler grinding-in with the forging into the optimal state. After achieving the optimal state, that is over 2000 items, the state of so-called normal operation begins (period II), characterizing in a more or less stabilized level of intensity of the previously mentioned wear phenomena, which, in the analyzed case, goes up to about 8000 items. The volume change for this forging range equals from 900 to $3516 \mathrm{~mm}^{3}$, whereas for 8000 items up to the end of the tool operation (over 12500 items), the volume change equals merely $350 \mathrm{~mm}^{3}$. On this basis, we can conclude that the state of stabilized wear can be assumed to be between 7000 and 8000 forgings, which can be treated as the beginning of period III of the wear period. This state, for the analyzed tool, is present up to the moment of maximal exploitation,

Fig. 8. Comparison of scans of the inner part of the forgings, in the form of quantitative shape changes in relation to the CAD model of the nominal forging, every: a) 2000, b) 3000, c) 4000, d)5000, e) 7000, f) 8000 items

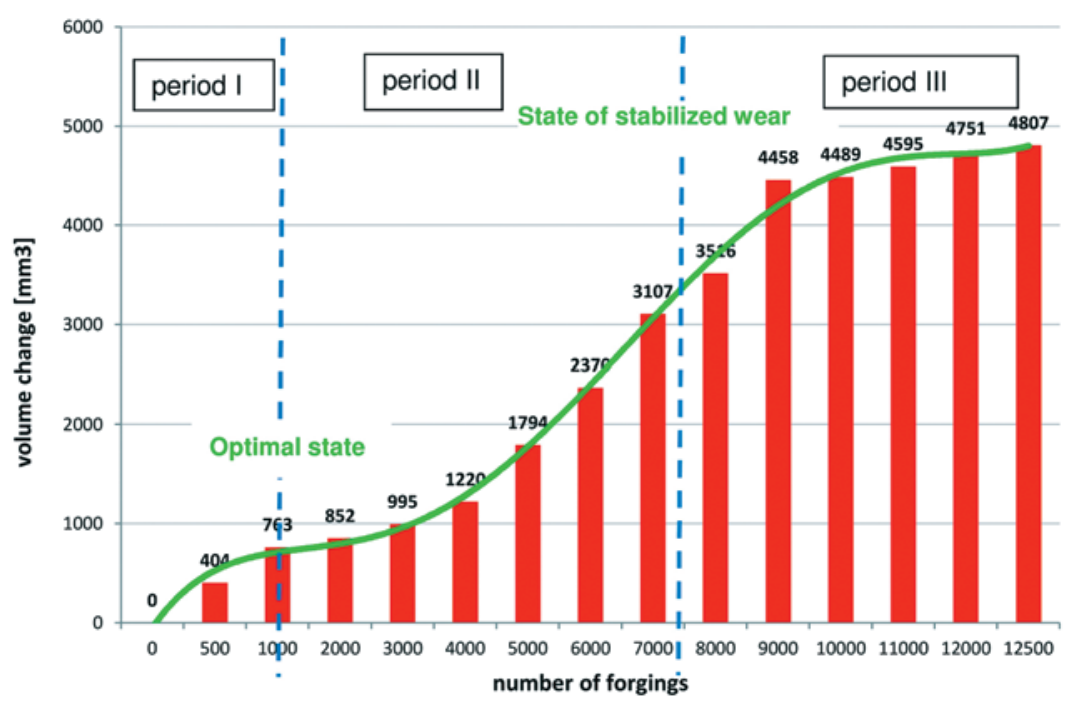

Fig. 9. Comparison of the material loss (volume changes) in the filler based on the volume changes on the surface of consecutive forgings that is 12500 items, and it finishes as a result of exceeding the acceptable shape change of the tool, due to its elimination from further production. The classic Lorenz curve, towards the end of the period of normal operation, usually turns into the state of accelerated wear, which, unfortunately, cannot be observed in the analyzed case. This can be explained by the reduced pressure exerted on the tool as a result of the proceeding wear of the contact surfaces of the tool and the formed forging.

In order to identify the destruction phenomena and mechanisms concerning the forging tools, the authors performed a series of laboratory tests. As a result of a cyclic operation of high thermo-mechanical loads in the whole exploitation period, the tools undergo many destructive phenomena, occurring with different intensity and frequency. The tests revealed that, in the initial period of the forging process (about 400-1000 items.), on the analyzed tools, as a result of thermal fatigue, we can observe a primary, and together with the increasing number of forgings, secondary fatigue crack network (Fig. 10). The effect of this is a relatively 


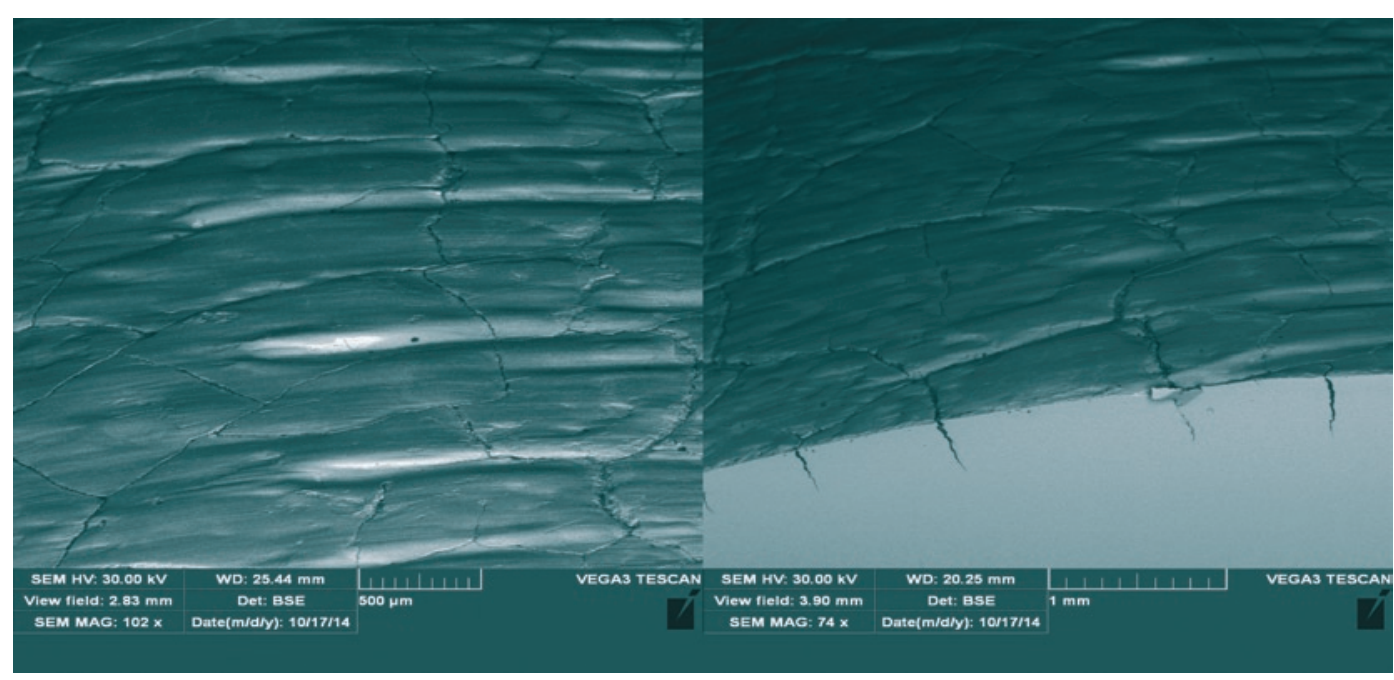

Fig. 10. Filler area (after 500 forgings) with primary and secondary crack network resulting from thermal fatigue, magnification 60x, scanning electron microscope TESCAN VEGA3

large loss (volume change at the level of $404 \mathrm{~mm}^{3}$, after about 400-500 forgings) of the tool material. What is more, the test results concerning the properties of the nitrided layer for this type of tools showed that, in the case of abrasive wear as the dominating destructive mechanism, in the initial period (400-500 forgings), we can observe a very rapid ,rubbing off" of the nitrided layer.

In turn, with a larger number of forgings (Fig. 11), after the mentioned stabilized wear has been reached, we can see numerous grooves (in the vicinity of the filler opening) as well as smaller and larger cracks, while it is difficult to observe the characteristic network of cracks originating from thermal fatigue.

The value of stabilized wear for the analyzed tool (up to 7000 items) is probably connected with the intensified abrasive wear, additionally supported by the detaching hard particles (nitrides from

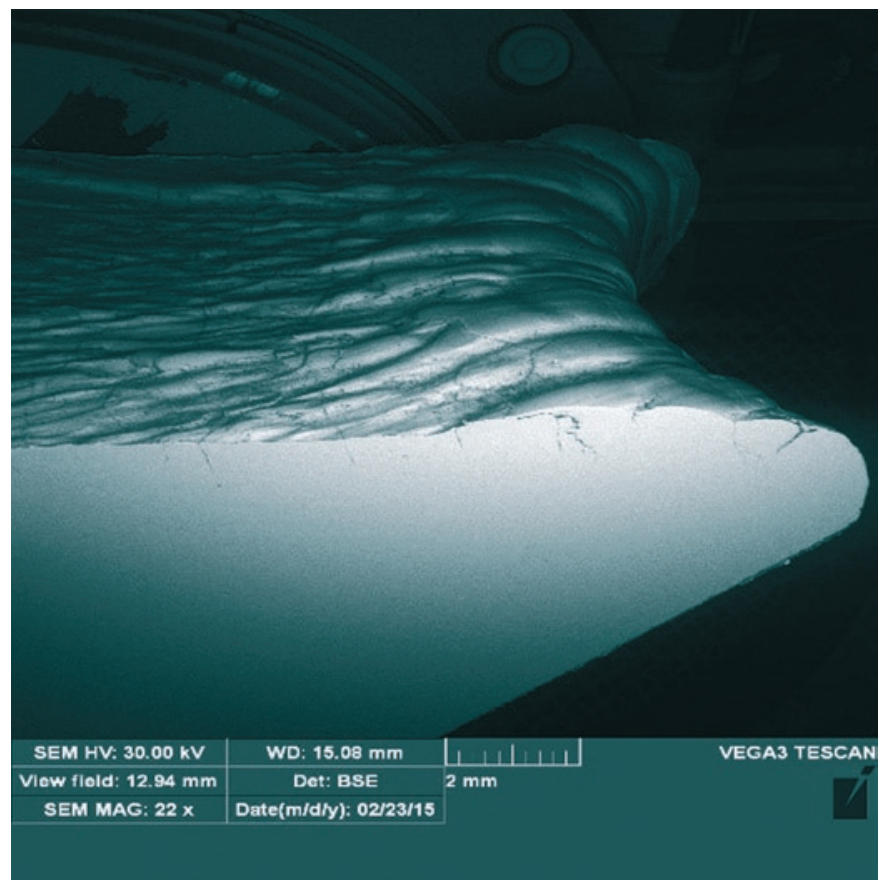

Fig. 11. Filler area in the vicinity of the opening (after 9000 forgings) with visible grooves ("washing out" of material) and microcracks, magnification 22x, scanning electron microscope TESCAN VEGA3 the nitrided layer and oxides of the tool material) in the surface layer of the tool, working as abradant.

As regards the range from 8000 to 12500 forgings, the almost constant wear value at the level of about 4440 to $4800 \mathrm{~mm} 3$ is connected with the reduced pressure on the worn tools (as compared to new ones), which was verified by way of numerical modeling of the forging process.

At present, the authors are conducting research concerning the analysis of the occurrence of the mentioned saturation level with the particular number of forgings for forging tools used in other hot die forging processes.

\section{Summary}

The performed research with the use of a measuring arm together with an integrated laser scanner for the analysis of the filler wear, on the basis of the measurements of the shape changes of consecutive forgings (directly on the production line) proved the validity of applying new measuring technologies in order to directly analyze the quality and change of the tool shape (without disassembling the instrumentation from the forging unit). Owing to this, such an analysis was possible directly during the production process.

The analysis of the volume growth of consecutive forgings based on the measurements makes it possible to precisely determine the material loss of the forging tool in the consecutive stages of its operation. This is proved by the full correlation between the results of the measurements of the volume changes of the series of the increasing number of produced forgings and the tool in the middle and towards the end of its work.

The innovative approach to evaluating the current state of the forging tool proposed by the authors makes it possible to make decisions about a prolongation or shortening of the time of its operation based on the actual (current) wear, and not on the basis of the strictly set tool life (maximal number of produced forgings). This allows for an optimal use of the given tool, with the preservation of the possibly highest quality of the produced forgings.

This method makes it possible to eliminate the human factor from the process of making decisions by way of determining the geometrical tolerance for the changing shape of the tools correlated with the tolerance and shape of the forgings.

What is more, the proposed method would allow for an early detection of the occurrence of disadvantageous changes during the forging process, such as inappropriate lubrication or a premature fracture of the tool and thus it would enable a fast reaction, that is a proper correction of the position of the lubricating nozzles or an immediate removal of the tool from the production, and retooling.

The exhibited advantages of the proposed new approach to the analysis of the state of the tool based on the measurements of the shape changes of the forgings, with the use of a laser scanner, would surely translate to a prolongation the tool life of the forging instrumentation and a significant reduction of the production costs. 


\section{References}

1. Bills P.J, Racasan R, Underwood R.J, Cann P, Skinner J, Hart A.J, Jiang X, Blunt L. Volumetric wear assessment of retrieved metal-on-metal hip prostheses and the impact of measurement uncertainty. Wear 2012; 274-275: 212-219, http://dx.doi.org/10.1016/j.wear.2011.08.030.

2. Carmignato S, Spinelli M, Affatato S, Savio E. Uncertainty evaluation of volumetric wear assessment from coordinate measurements of ceramic hip joint prostheses. Wear 2011; 270(9-10): 584-590, http://dx.doi.org/10.1016/j.wear.2011.01.012.

3. Farooqui S.A, Morse E.P.: Methods and artifacts for comparison of scanning CMM performance. Journal of Computing and Information Science in Engineering 2007; 7(1): 72-80, http://dx.doi.org/10.1115/1.2709928.

4. Gąska A, Olszewska M. Ocena odwzorowania kształtu za pomocą współrzędnościowego ramienia pomiarowego wyposażonego w głowicę optyczną. Postępy Nauki i Techniki 2011; 7: 37-43.

5. Gronostajski Z, Hawryluk M, Kaszuba M, Niechajowicz A, Polak S, Walczak S, Jabłoński D. Die profile optimization for forging constant velocity joint casings. Archives of Metallurgy and Materials 2011; 56(2): 551-558, http://dx.doi.org/10.2478/v10172-011-0059-z.

6. Gronostajski Z, Hawryluk M, Niechajowicz A, Zwierzchowski M, Kaszuba M, Będza T. Application of the scanning laser system for the wear estimation of forging tools. Computer Methods in Materials Science 2011; 11(2): 425-431.

7. Gronostajski Z, Hawryluk M. The main aspects of precision forging. Archives of Civil and Mechanical Engineering 2008; 8(2): 39-55, http:// dx.doi.org/10.1016/S1644-9665(12)60192-7.

8. Gronostajski Z, Kaszuba M, Hawryluk M, Marciniak M, Zwierzchowski M, Mazurkiewicz A, Smolik J. Improving durability of hot forging tools by applying hybrid layers. Metallurgy 2015; 54(4): 687-690.

9. Gronostajski Z, Kaszuba M, Hawryluk, M, Zwierzchowski M. A review of the degradation mechanisms of the hot forging tools. Archives of Civil and Mechanical Engineering 2014; 14(4): 528-539, http://dx.doi.org/10.1016/j.acme.2014.07.002.

10. ISO GPS 10360-4:2000 Geometrical Product Specifications (GPS) - Acceptance and Reverification Tests for Coordinate Measuring Machines (CMM) - Part 4: CMMs used in Scanning Measuring Mode. Norma.

11. Kawalec A, Magdziak M. Metoda obliczania krzywej offset. Przegląd Mechaniczny 2011; 70(7-8): 26-30.

12. Kawalec A, Magdziak M. Wpływ metody dopasowania na wyniki pomiarów pióra łopatki, XI Forum Inżynierskie ProCAx, $2012 ; 2$.

13. Kontrola jakości odkuwek i matryc - archiwizacja i regeneracja matryc. Materiały informacyjne: ITA-polska; http://www.ita-polska.com.pl.

14. Kuş A. Implementation of 3d optical scanning technology for automotive applications. Sensors 2009; 9: 1967-1979, http://dx.doi.org/10.3390/s90301967.

15. Langton D.J, Sidaginamale R.P, Holland J.P, Deehan D, Joyce T.J, Argol A.F, Meek R.D, Lord J.K. Practical considerations for volumetric wear analysis of explanted hip arthroplasties. Bone \& Joint Research 2014; 3: 60-68, http://dx.doi.org/10.1302/2046-3758.33.2000249.

16. Li F. X, Longstaff A, Fletcher S, Myers S. Integrated tactile and optical measuring systems in three dimensional metrology. Computing and Engineering Researchers' Conference, University of Huddersfield, Mar 2012; 1-6.

17. Lord J.K, Langton D.J, Nargol A.V.F, Joyce T.J. Volumetric wear assessment of failed metal-on-metal hip resurfacing prostheses. Wear 201; 272(1): 79-87.

18. Lu Z1, McKellop HA. Accuracy of methods for calculating volumetric wear from coordinate measuring machine data of retrieved metal-on-metal hip joint implants. Proceedings of the Institution of Mechanical Engineers, part H 2014; 228(3): 237-49, http://dx.doi. org/10.1177/0954411914524188.

19. Lulkiewicz J, Szkudelski S, Pachutko B. Kompleksowe badania matryc kuźniczych. Projektowanie i Konstrukcje Inżynierskie 2015; 3(90):16-19.

20. Machácek, P, Tomícek J. Application of laser scanning in reverse engineering and prototype manufacturing. WTP 2010; 1(21): 35-44.

21. Magdziak M. Metoda pomiaru powierzchni swobodnych na obrabiarce sterowanej numerycznie. Praca doktorska, Wydział Budowy Maszyn i Lotnictwa, Politechnika Rzeszowska, Rzeszów 2012.

22. Marton E, Pizzolon F. Dimensional control during forging. Innovative 3d laser measuring systems, Forge Applications 2010; (1).

23. Measurement of a forging die for tooling corrections. Materiały informacyjne: AICON_3D_SYSTEM; http://www.aicon3d.com/fileadmin/ user_upload/produkte/ en/breuckmann_Scanner/ 01_PDF_IuT/Forging_die_measurement_Web.pdf.

24. Pachutko B, Ziółkiewicz S. Investigation of the wear processes of dies for forging building anchors basing on metallographic examinations. Obróbka Plastyczna Metali 2012; 23(4): 277-293.

25. Peng X., Wang L., Yang W., Zhao Y., Li D., Jin Z., Fan B., Dong S., Zhang S.: Optimized adaptive control for evaluation of artificial hip joint volumetric wear by coordinate measuring. Hsi-An Chiao Tung Ta Hsueh/Journal of Xi'an Jiaotong University 2014; 48(8): 128-135.

26. Salah Hame, R. A. Influence of fitting algorithm and scanning speed on roundness error for $50 \mathrm{~mm}$ standard ring measurement using CMM. Metrology and Measurement Systems 2008; 15(1): 33-53.

27. Ulatowski K. Ramiona pomiarowe - rynek i zastosowania. Magazyn Przemysłowy 2013; http://www.magazynprzemyslowy.pl/zarzadzaniei-rynek/Ramiona-pomiarowe-rynek-i-zastosowania.

28. Weckenmann A, Weickmann J. Optical inspection of formed sheet metal parts applying fringe projection systems and virtual fixation. Metrology and Measurement Systems 2006; 13(4): 321-334.

\section{Zbigniew GRONOSTAJSKI \\ Marek HAWRYLUK \\ Marcin KASZUBA \\ Jacek ZIEMBA}

Department of Mechanical Engineering

Wroclaw University of Technology

Wybrzeże Wyspiańskiego 27, 50-370 Wrocław, Poland

E-mails: zbigniew.gronostajski@pwr.edu.pl,marek.hawryluk@pwr.edu.pl, marcin.kaszuba@pwr.edu.pl, jacek.ziemba@pwr.edu.pl 